\title{
THE IMPACT OF THE CANADIAN COPYRIGHT ACT ON THE VOICES OF MARGINALIZED GROUPS
}

\author{
GRAHAM REYNOLDS*
}

For as long as stories have been written, they have been rewritten. Authors rewrite texts for a variety of reasons. This article will focus on one particular type of rewriting - namely, the rewriting of culturally significant texts from the perspective of marginalized groups that are either missing from or oppressed in the original text. These rewrites serve important social purposes. However, it is likely that many of these rewrites infringe Canadian copyright laws and laws with respect to moral rights. This article argues that works that rewrite culturally significant texts from the perspective of marginalized groups ought not to infringe copyright and violate moral rights in Canada. To this end, it suggests five amendments to Canada's Copyright Act that would help ensure that the attempts by marginalized groups to express themselves through the rewriting of culturally significant texts cannot be enjoined by copyright owners and authors. Some of these proposed amendments have been incorporated into Bill C-32 (An Act to Amend the Copyright Act), the Government of Canada's latest attempt at copyright reform.
Depuis l'époque où l'on écrit des histoires, on les récrit. Les auteurs récrivent des textes pour un nombre de raisons. Cet article examine un type précis de réécriture, notamment, celle des textes importants sur le plan culturel du point de vue de groupes marginalisés qui sont absents du texte original ou qui y sont opprimés. Ces réécritures ont des raisons d'être sociales très importantes. Cependant, il est probable que nombre de ces réécritures vont à l'encontre des droits d'auteur canadiens et des lois relatives aux droits moraux. Cet article fait valoir que les œuvres qui récrivent les textes de valeur culturelle du point de vue de groupes marginalisés ne devraient pas aller à l'encontre des droits d'auteurs ou des droits moraux du Canada. C'est pourquoi, l'auteur suggère cinq amendements à la Loi sur le droit d'auteur du Canada qui aideraient à veiller à ce que les tentatives des groupes marginalisés à s'exprimer en récrivant des textes de valeur culturelle ne puissent pas être interdits par les titulaires de droits d'auteurs et les auteurs. Certains amendements ont été incorporés dans le Projet de loi C-32 (Loi modifiant la Loi sur le droit d'auteur), dernière tentative de réforme du droit d'auteur par le gouvernement du Canada.

\section{TABLE OF CONTENTS}

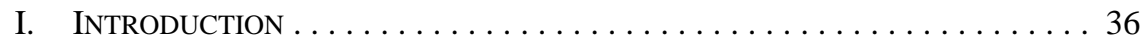

II. REWRITING CULtURALly SignifiCANT TEXTS $\ldots \ldots \ldots \ldots \ldots \ldots . \ldots 38$

III. REWRITES AND COPYRIGHT INFRINGEMENT $\ldots \ldots \ldots \ldots \ldots \ldots \ldots \ldots$

IV. REWRites AND THE FAIR DEALING DEFENCE $\ldots \ldots \ldots \ldots \ldots \ldots \ldots 42$

V. REWRITES AND MORAL RIGHTS INFRINGEMENT $\ldots \ldots \ldots \ldots \ldots \ldots . \ldots 8$

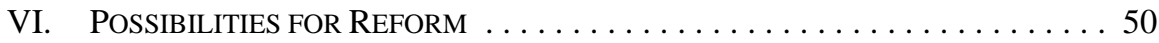

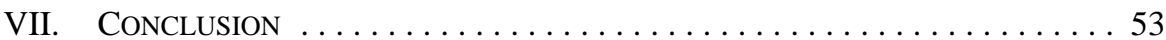

B.A. (Man.), LL.B (Dal.), B.C.L., M.Phil. (Oxon.). Assistant Professor, Dalhousie University, Schulich School of Law, Halifax, Nova Scotia; a member of Dalhousie University's Law and Technology Institute; Co-Editor-in-Chief, Canadian Journal of Law and Technology. 
It is impossible ... for the law to remain neutral in this contest. The law can strengthen the already potent grip of the culture industries over the production and circulation of meaning, or it can facilitate popular participation, including participation by subordinate and marginalized groups, in the processes by which meaning is made and communicated. The law can accelerate the already powerful trend toward centralized, top-down management of popular culture, or it can fight a rearguard (and perhaps futile) action on the side of a more decentralized, open, democratic cultural practice. ${ }^{1}$

\section{INTRODUCTION}

For as long as stories have been written, they have been rewritten. ${ }^{2}$ It has been suggested that the Book of Genesis is a rewrite of an "ancient Mesopotamian fertility story of sex and

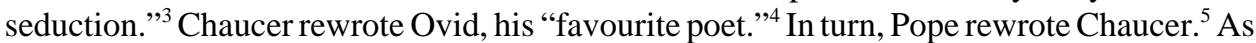
Hayden Carruth has noted, "Shakespeare rewrote Boccaccio and in turn was rewritten by Lamb. Fitzgerald is as clearly present as Omar in the Rubaiyat." ${ }^{6}$ James Joyce's Ulysses, ${ }^{7}$ Robert Kroetsch's The Studhorse Man, ${ }^{8}$ the motion picture O Brother, Where Art Thou?, ${ }^{9}$ Derek Walcott's The Odyssey: A Stage Version, ${ }^{10}$ and Margaret Atwood's Penelopiad ${ }^{11}$ are all rewrites of Homer's Odyssey. Amateur authors, as well as professionals, rewrite works. Through the genre of fan fiction, many amateur authors have rewritten, revised, and recast their favorite novels, movies, and television shows.

Authors rewrite texts for a variety of reasons, including the desire to make a classic text relevant to one's own culture or age; to capitalize on the popularity of a prior work for profit; to pull a forgotten text out of obscurity; to engage, creatively, with a text to which the author attaches personal significance; and to critique certain aspects of either the original work or of society. This article will focus on one particular type of rewriting - namely, the rewriting of culturally significant texts from the perspective of a marginalized group that is either missing from or oppressed in the original text.

The act of rewriting culturally significant texts is a powerful tool of criticism and empowerment for women and minority groups worldwide. ${ }^{12}$ Both amateur and professional writers create these types of rewrites, which range from fan fiction authors incorporating characters from marginalized groups into new episodes of their favourite written works or television programs, to established authors responding to, reorienting, and recasting major

Michael Madow, “Private Ownership of Public Image: Popular Culture and Publicity Rights” (1993) 81 Cal. L. Rev. 125 at $141-42$.

See Jeannie Suk, “Originality,” Note, (2002) 115 Harv. L. Rev. 1988 at 1989 for an extensive list of instances of rewriting.

3 J. Harold Ellens, Sex in the Bible: A New Consideration (Westport, Conn.: Praeger, 2006) at 55.

$4 \quad$ Michael A. Calabrese, Chaucer's Ovidian Arts of Love (Gainesville: University Press of Florida, 1994) at 23 .

Hayden Carruth, "Foreword” in Stephen Berg, With Akhmatova at the Black Gates (Urbana: University of Illinois Press, 1981) at ix.

Ibid.

James Joyce, Ulysses (New York: Random House, 1946).

Robert Kroetsch, The Studhorse Man, 10th ed. (Edmonton: University of Alberta Press, 2004).

O Brother, Where Art Thou?, 2000, DVD (Burbank, Cal.: Touchstone Pictures, 2001).

Derek Walcott, The Odyssey: A Stage Version (New York: Farrar Straus Giroux, 1993).

Margaret Atwood, The Penelopiad (New York: Canongate, 2006).

See Abigail Derecho, "Archontic Literature: A Definition, a History, and Several Theories of Fan Fiction,” in Karen Hellekson \& Kristina Busse, eds., Fan Fiction and Fan Communities in the Age of the Internet (Jefferson, N.C.: McFarland, 2006) 61 at 61. 
works of literature from alternative points of view — from Harry Potter "slash" fan fiction, which imagines same-sex romantic relationships among characters from the Harry Potter series, ${ }^{13}$ to The Wind Done Gone, ${ }^{14}$ a rewrite of Gone With the Wind ${ }^{15}$ from the perspective of a former slave on the O’Hara plantation.

These rewrites serve important cultural purposes. They expose, challenge, and correct stereotypes found in the original work. As well, they "highlight the oppressed or 'silent' minority perspectives in the original text," ${ }^{16}$ giving individuals an opportunity to write these "missing voices" into central roles in mainstream cultural discourse ${ }^{17}$ In so doing, these types of rewrites help empower marginalized groups. ${ }^{18}$

It is likely, however, that many works that rewrite culturally significant texts from the perspective of marginalized groups prima facie infringe copyright. Furthermore, there is a strong possibility that some rewrites will not be saved by the fair dealing defence, as set out in the Copyright $A c t^{19}$ and interpreted by Canadian courts. Some rewrites may also be found to violate the original author's moral rights.

This article argues that works which rewrite culturally significant texts from the perspectives of marginalized groups serve important social purposes and, as a result, ought not to infringe copyright or violate moral rights in Canada. ${ }^{20}$ In permitting copyright owners to suppress rewritten versions of their texts - versions that expose stereotypes, challenge "dominant cultural norms," 21 highlight missing voices, and help empower women and minority groups ${ }^{22}$ - Canadian copyright and moral rights laws unjustly suppress the voices of marginalized groups.

In seeking to create a legal space within which individuals can rewrite culturally significant texts from the perspective of marginalized groups, this article suggests five

Anupam Chander \& Madhavi Sunder, “Everyone’s a Superhero: A Cultural Theory of 'Mary Sue’ Fan Fiction as Fair Use” (2007) 95 Cal. L. Rev. 597 at 609. See Harry Potter Fanfiction, online: Harry Potter Fanfiction <http://www.harrypotterfanfiction.com>; Mugglenet, "Mugglenet Fan Fiction," online: Mugglenet $<$ http://www.fanfiction.mugglenet.com>.

Alice Randall, The Wind Done Gone (Boston: Houghton Mifflin, 2001).

Margaret Mitchell, Gone with the Wind (New York: Macmillan, 1975).

Zahr Said Stauffer, “'Po-mo Karaoke’ or Postcolonial Pastiche? What Fair Use Analysis Could Draw From Literary Criticism” (2008) 31 Colum. J.L. \& Arts 43 at 43, n. 3.

Suk, supra note 2 at 1992.

Chander \& Sunder, supra note 13 at 599.

R.S.C. 1985 , c. C-42.

This article is not taking the position that all rewrites ought to be permitted under copyright laws. Copyright owners should have the right to enjoin certain rewrites of their works (for instance, rewrites that act as unauthorized sequels created solely in the pursuit of profit). As noted by the Supreme Court of Canada in Théberge v. Galerie d'Art du Petit Champlain Inc., 2002 SCC 34, [2002] 2 S.C.R. 336 [Théberge], the Copyright Act is seen as a balance between "promoting the public interest" and "obtaining a just reward for the creator" (at para. 30). The proper balance in the case of rewrites, however, ought not result in giving the copyright owner the ability to control all rewrites of their works. Particularly, the copyright owner ought not to be able to enjoin rewrites from the perspective of marginalized groups. As stated by the Supreme Court, "[t]he proper balance ... lies not only in recognizing the creator's rights but in giving due weight to their limited nature. In crassly economic terms it would be as inefficient to overcompensate artists and authors ... as it would be self-defeating to undercompensate them” (at para. 31). To allow copyright owners to control rewrites of culturally significant texts in which they own copyright from the perspective of marginalized groups overcompensates those owners at the expense of the public interest.

21 Jacqueline Lai Chung, "Drawing Idea from Expression: Creating a Legal Space for Culturally Appropriated Literary Characters,” Note, (2007) 49 Wm. \& Mary L. Rev. 903 at 917.

See Chander \& Sunder, supra note 13 at 626. 
amendments to the Canadian Copyright Act. Some of these amendments have been proposed in Bill C-32 (An Act to Amend the Copyright Act), ${ }^{23}$ Canada's latest attempt to amend the Copyright Act. Other amendments could be incorporated into Bill C-32 at a later stage in the legislative process.

First, the "substantial taking" requirement could be modified to take into consideration the extent to which the allegedly infringing work is "transformative." Second, the Copyright Act could be amended to include parody and satire defences to copyright infringement. Third, the Copyright Act could be amended to incorporate a right to engage in the transformative use of copyright-protected expression. Fourth, a right to use existing expression in the creation of new expression, provided the use is done for non-commercial purposes, could be incorporated into the Copyright Act. Fifth, the fair dealing defence could be revised to indicate that fair dealing neither infringes copyright nor violates moral rights.

Adopting these solutions would help Canada's copyright laws achieve a more equitable balance between the rights of copyright owners, authors, and users, particularly users from marginalized groups. While maintaining the rights of the copyright owner to control the commercial exploitation of their work and the rights of the author to enjoin certain mutilations, distortions, and modifications of their work, these solutions, if adopted, would help ensure that the attempts by marginalized groups to express themselves through the rewriting of culturally significant texts cannot be enjoined by copyright owners and authors.

This article will proceed in five parts. First, it will argue that the act of rewriting a culturally significant text from the perspective of a marginalized group serves important social purposes. Second, it will discuss whether this form of rewriting infringes copyright in Canada. Third, it will examine whether this form of rewriting is protected under the fair dealing defence. Fourth, it will discuss rewrites and moral rights infringement. Fifth, in the attempt to create a legal space within which individuals can rewrite culturally significant texts from the perspective of marginalized groups, this article will propose five amendments to Canada's Copyright Act.

\section{REWRITING CUlturally SignifiCANT TEXTs ${ }^{24}$}

The act of rewriting culturally significant texts from the perspective of marginalized groups is rooted in the postcolonial critical theory movement. ${ }^{25}$ This movement is generally said to have been "set in motion" in the mid to late 1970s with the publication of Edward Said's book Orientalism, ${ }^{26}$ and has "developed into a body of critical literature that considers all forms of narrative discourse produced by authors who are or were subject to colonialism

Bill C-32, An Act to amend the Copyright Act, 3rd Sess., 40th Parl., 2010 (first reading 2 June 2010). For the purposes of this article, a work is deemed culturally significant if it is well-known - if it is part of our "shared cultural vocabulary": Suk, supra note 2 at 1993. Works become part of our shared cultural vocabulary for a variety of reasons, including the quality of the work, the ubiquitousness of the work, reviews or awards that bring the work to the attention of the general public, and money spent marketing the work. As well, a broad definition of "text" will be adopted: movies, books, visual art, television programs, and radio broadcasts are all considered "texts" for the purposes of this article. Ibid. at 1992-93.

Edward W. Said, Orientalism (New York: Random House, 1978). Stauffer notes that "Chinua Achebe's 1975 lecture on the racism in Conrad's Heart of Darkness was also an important milestone" in the emergence of the postcolonial movement: supra note 16 at 46. 
or are, in less direct ways, struggling with a longer term or indirect experience of the colonial legacy." 27 Postcolonial critics “consciously '[write] back' to canonical texts. These countertexts [write] within gaps and omissions, supplying missing voices and reclaiming a past that the colonizer had previously written."28

One way to write back to a text is by rewriting it from the perspective of a marginalized group that was either missing from the original text or hidden in its margins. Some rewrites reorient texts from the point of view of a character from a marginalized group that has a minor (and, in some cases, non-speaking) role in the original text. One such work is Alice Randall's The Wind Done Gone, a remake of Gone With the Wind from the perspective of Cynara, Scarlett O’Hara's half-sister (according to Randall) and a former slave on the O'Hara plantation. The Wind Done Gone "upend[s] Mitchell's idealized portrait [of the 'antebellum South during and after the Civil War' ${ }^{29}$ ] by deploying its very story lines, scenes, and characters to reimagine them from the viewpoint of a slave."30 Another example of a work rewritten from the point of view of a character from an oppressed group that has a minor role in the original text is Jean Rhys's Wide Sargasso Sea. ${ }^{31}$ In this postcolonial critique, Rhys recounts the history of Bertha Mason, Edward Rochester's first wife, a woman of Creole heritage, and the madwoman in the attic in Jane Eyre.

In creating these rewrites, authors reclaim minority interests from the fringes or margins of a text. For individuals from marginalized groups seeking a place at the centre of mainstream cultural discourse, this action is often necessary. Henry Jenkins notes that "[f]emale characters often exist only in the margins of male-centered narratives." 32 As Teresa de Lauretis has stated: "Medusa and the Sphinx, like the other ancient monsters, have survived inscribed in hero narratives, in someone else's story, not their own; so they are figures or markers of positions — places and topoi — through which the hero and his story move to their destination and to accomplish meaning."33

While some rewrites thrust characters from marginalized groups from the fringes of texts to their centres, other rewrites reimagine a text from the perspective of a marginalized group that is absent in the original work. In these rewrites, members of marginalized groups are inserted into the text. The absent voice is given presence as the authors "pry open space for [the] cultural concerns [of marginalized groups] within dominant representations." 34 By placing the concerns of marginalized groups — both those missing from a text or hidden in its margins - at the centre of contemporary cultural discourse, rewrites help empower marginalized groups. ${ }^{35}$

Stauffer, ibid

Suk, supra note 2 at 1992-93.

Suntrust Bank v. Houghton Mifflin Co., 268 F.3d 1257 at 1270 (11th Cir. 2001).

Neil Weinstock Netanel, Copyright's Paradox (Oxford: Oxford University Press, 2008) at 159.

Jean Rhys, Wide Sargasso Sea (London: Deutsch, 1966).

Henry Jenkins III, “Star Trek Rerun, Reread, Rewritten: Fan Writing as Textual Poaching,” in Horace Newcomb, ed., Television: The Critical View, 5th ed. (Oxford: Oxford University Press, 1994) 448 at 455.

33 Teresa de Lauretis, Alice Doesn't: Feminism, Semiotics, Cinema (Bloomington: Indiana University Press, 1984) at 109, cited in Jenkins, ibid.

Jenkins, ibid. at 450.

Citing Cheryl Harris, Professors Chander and Sunder, supra note 13, remark at 599 that "[c]ultural studies scholars define 'empowerment' 'as a function and possibility of participation in popular culture'”: Cheryl Harris, “A Sociology of Television Fandom,” in Cheryl Harris \& Alison Alexander, eds., Theorizing Fandom: Fans, Subculture and Identity (Cresskill, N.J.: Hampton Press, 1998) 41 at 42. 
In the process of creating such rewrites as those noted above, many authors also expose, challenge, and "upend" 36 stereotypes or "majority representations of characters ... with respect to race, gender, sexuality," and other social factors contained within the original work. ${ }^{37}$ For instance, Randall's work, The Wind Done Gone, took aim at the "oppressive stereotypes that sustain Mitchell's idealized portrait” of the antebellum South. ${ }^{38}$ Jenkins notes that many fan fiction writers challenge the majority representations of characters on television shows with respect to gender. ${ }^{39}$ Describing Star Trek, fan writer Toni Lay states that “[m]ost of the time, women were referred to as 'girls.' And women were never shown in a position of authority unless they were aliens." 40

Stereotypes persist in today’s popular media. In their article "Everyone's a Superhero: A Cultural Theory of 'Mary Sue' Fan Fiction as Fair Use,” Professors Anupam Chander and Madhavi Sunder conclude, after surveying social science research tracking stereotypes in the popular media, that the cultural landscape remains "patriarchal, heterosexist, and racially stereotyped.” ${ }^{41}$ Rewrites can help expose, challenge, and debunk these stereotypes.

However, although the act of rewriting culturally significant texts from the perspective of marginalized groups serves important societal purposes, it may also infringe copyright. Part III will proceed by discussing whether rewrites infringe copyright law in Canada.

\section{REWRITES AND COPYRIGHT INFRINGEMENT}

Anyone can rewrite a text that is no longer protected by copyright without being subject to a successful action for copyright infringement. Charles Dickens' heirs cannot enjoin the creation of a remake of Great Expectations set in North Winnipeg. Leonardo Da Vinci's heirs cannot enjoin the creation of a female version of the Vitruvian Man. Homer's heirs cannot stop a Canadian playwright rewriting the Odyssey from an Aboriginal perspective. Many individuals, however, rewrite texts that are still protected by copyright. ${ }^{42}$ As a result, rewrites may run afoul of copyright law.

Copyright, in Canada, is a creature of statute. ${ }^{43}$ The rights and obligations of copyright owners and users are set out in the Copyright Act. "[O]riginal literary, dramatic, musical and artistic works, ${ }^{44}$ and, in certain cases, fictional characters, ${ }^{45}$ are protected by copyright. A person infringes copyright by doing, without the permission of the copyright owner, any of

Netanel, supra note 30 at 159 .

Chung, supra note 21 at 917.

Netanel, supra note 30 at 41.

Supra note 32 at 457.

Toni Lay, Letter, (1986) 28 Comlink 14 at 15, cited in Jenkins, ibid.

Supra note 13 at 601 .

This is due, in large part, to the length of the term of copyright in Canada. For literary, dramatic, musical, and artistic works, the period of copyright is the life of the author plus 50 years: Copyright Act, supra note 19, s. 6. As a result, a large proportion of the shared cultural vocabulary is unavailable to be rewritten without risking a lawsuit from copyright owners.

43 Euro-Excellence v. Kraft Canada, 2007 SCC 37, [2007] 3 S.C.R. 20 at para. 3; CCH Canadian Ltd. v. Law Society of Upper Canada, 2004 SCC 13, [2004] 1 S.C.R. 339 at para. 9 [CCH Canadian]; Théberge, supra note 20 at para. 5; Bishop v. Stevens, [1990] 2 S.C.R. 467 at 477; Compo Co. Ltd. v. Blue Crest Music, [1980] 1 S.C.R. 357 at 372-73.

$44 \quad$ Copyright Act, supra note 19, s. 5(1).

$45 \quad$ See Preston v. 20th Century Fox Canada Ltd. (1990), 38 F.T.R. 183 (T.D.) [Preston]. 
the acts that only the copyright owner has the right to do. ${ }^{46}$ Copyright owners' rights with respect to literary, dramatic, musical, or artistic works, include the right to reproduce the work or any substantial part of the work in any material form, to perform the work or any substantial part of the work in public, to produce any translation of the work, to make any sound recording of a literary work, and to communicate a work to the public by telecommunication. ${ }^{47}$

The rights of the copyright owner in an original work may be infringed through both the creation and distribution of rewritten versions of that work. The creation of rewrites may prima facie infringe the right of the person who owns copyright in the original work to reproduce the work or a substantial part of the work. Unless there is a defence set out in the Copyright Act upon which the author of the rewrite may rely, the reproduction of a "substantial” part of a copyright-protected work without the permission of the copyright owner will constitute copyright infringement. One can infringe copyright both through literal copying (copying verbatim from the original work; for instance, by lifting passages of descriptive prose or dialogue from one text and inserting it into another work) and through non-literal copying (taking elements of the work such as plot, setting, characters, etc., without actually copying verbatim from the original work).

The question of whether the allegedly infringing work has taken a substantial portion of the original work (and thus prima facie infringed copyright) depends on both the quality of the material taken as well as the quantity of material taken. If the amount taken is qualitatively significant (for instance, the "hook" of a popular song ${ }^{48}$ ), a small taking can be sufficient to constitute copyright infringement.

In creating rewrites, authors take varying amounts of plot, character, setting, and dialogue from the original works. Some rewrites take only the main character of the original work, placing them in a new setting with a different cast of characters. For instance, some Harry Potter fan fiction imagines Harry in a completely new context (such as Churchill, Manitoba). Though a Canadian court has not had the opportunity to make a decision on such a question, there is a strong possibility that a court would determine that rewrites that feature the main character of a copyright-protected work have reproduced a substantial part of the original work. $^{49}$

Other rewrites draw significantly from the plot, character, or setting of the original work, presenting it from a new perspective. Rewrites falling into this category include The Wind Done Gone and Wide Sargasso Sea. Fan fiction that reimagines a culturally significant text from an alternative perspective (for instance, that reimagines the Simpsons as a family of Asian Canadians, or that replaces the character of Ron Weasley from the Harry Potter books

Copyright Act, supra note 19, s. 27.

Ibid., s. 3(1).

Grignon v. Roussel (1991), 44 F.T.R. 121 (T.D.).

Additionally, some fictional characters are protected by copyright independently of the works within which they are featured. Specifically, fictional characters that are "sufficiently clearly delineated in the work subject to copyright that [they] become widely know and recognized” are protected by copyright in Canada: Preston, supra note 45 at para. 72 [footnotes omitted]. The inclusion of fictional characters protected by copyright into a new work, without the permission of the copyright owner, will prima facie infringe copyright. 
with an African-Canadian character, and tells the story from his perspective) would also fall into this category. It is likely that a court will determine that a rewrite that uses the same setting, a similar plot, and similar characters to the original work is reproducing a substantial amount from the copyright-protected work, thus prima facie infringing copyright.

Individuals may also prima facie infringe copyright through the distribution of rewritten versions of culturally significant texts. If authors of rewrites post their works online (for instance, on fan fiction websites), they may be found to have prima facie infringed the copyright owner's exclusive right to communicate the work to the public by telecommunication. ${ }^{50}$ They may also be found to have authorized reproductions of the work. Under the Copyright Act, an individual "authorizes" an act if they "sanction, approve and countenance" the act. ${ }^{51}$ Countenance has been further defined by the Supreme Court of Canada as meaning to "[g]ive approval to; sanction, permit; favour, encourage." ${ }^{\text {C }}$ A court may determine that by posting a rewrite online and making it available for download, individuals are prima facie infringing copyright by authorizing reproductions of the work.

Having established that, in many cases, rewritten versions of culturally significant texts will prima facie infringe copyright, Part IV of this article will proceed by discussing whether the fair dealing defence can apply to render these works non-infringing.

\section{REWRITES AND THE FAIR DEALING DEFENCE}

While various defences to copyright infringement are set out in the Copyright Act, the defence that is particularly relevant in the case of rewritten versions of culturally significant texts is fair dealing. Set out in ss. 29, 29.1, and 29.2 of the Copyright Act, the fair dealing defence states, in general terms, that the use of a substantial part of an individual's copyrightprotected expression will not constitute copyright infringement if the work is used for certain purposes, if the use is "fair," and if the author identifies the author of the work and the source of the work. ${ }^{53}$

For years, many courts interpreted the fair dealing defence restrictively, viewing it as a "limitation" on the copyright holder's exclusive rights. ${ }^{54}$ In two cases decided in 2002 and 2004, however, the Supreme Court of Canada shifted away from this view in favour of one that conceives of the fair dealing defence as an "integral part of the Copyright Act" and as a user's right. ${ }^{55}$ In $\mathrm{CCH}$ Canadian, McLachlin C.J.C., writing for the Court, stated that

[t]he fair dealing exception, like other exceptions in the Copyright Act, is a user's right. In order to maintain the proper balance between the rights of a copyright owner and users' interests, it must not be interpreted

See Society of Composers, Authors and Music Publishers of Canada v. Canadian Association of Internet Providers, 2004 SCC 45, [2004] 2 S.C.R. 427.

CCH Canadian, supra note 43 at para. 38 .

52 Ibid., citing the New Shorter Oxford English Dictionary on Historical Principles, 1993, s.v. "countenance."

53 Supra note 19. The requirement of noting the author of the work and the source of the work is not required for works produced for the purposes of research and private study.

54 Robertson v. Thomson Corp. (2004), 72 O.R. (3d) 481 at para. 36 (C.A.); Cie Générale Des Établissements Michelin-Michelin \& Cie v. C.A.W.-Canada (1996), [1997] 2 F.C.306 (T.D.) [Michelin]; Boudreau v. Lin (1997), 150 D.L.R. (4th) 324 (Ont. Ct. J. (Gen. Div.)) [Boudreau].

55 CCH Canadian, supra note 43 at para. 53; Théberge, supra note 20. 
restrictively. As Professor Vaver has explained: "User rights are not just loopholes. Both owner rights and user rights should therefore be given the fair and balanced reading that befits remedial legislation."56

The fair dealing analysis proceeds in three steps. First, the allegedly infringing act must have been for the purpose of research, private study, criticism, review, or news reporting. Second, acts done for the purposes of criticism, review, or news reporting must have mentioned both the source of the original work and the name of the author of the original work. Third, the dealing with the original work must have been fair. The term "fair" is not defined in the Copyright Act. However, the Supreme Court has set out a list of factors to provide a "useful analytical framework ... [governing] determinations of fairness." "57 These factors include: the purpose of the dealing, the character of the dealing, the amount of the dealing, alternatives to the dealing, the nature of the work, and the effect of the dealing on the work. ${ }^{58}$

As noted above, the first step in the fair dealing analysis requires the court to determine whether the work was created for one of the purposes listed in the Copyright Act. In order to "ensure that users' rights are not unduly constrained," the Supreme Court of Canada has said that these categories should not be interpreted restrictively ${ }^{59}$ The category of "research" is not limited to private or non-commercial contexts. Thus, the fact that a rewrite may be distributed publicly or sold commercially will not remove it from the ambit of the research category for fair dealing purposes. It is possible that some rewrites are created for the purposes of research (for instance, if the author of this article had created various rewrites in the process of researching and planning this article). However, it is unlikely, even given this expansive definition, that the majority of rewrites are created for the purpose of research, meaning that this category will likely be of little assistance to many authors of rewrites.

Rewrites that were created in private and not distributed could be seen as having been created for the purpose of private study. Many rewrites, however, are distributed to a broader community. Rewrites by established authors are distributed widely through both online bookstores and brick and mortar bookstores. Fan fiction is distributed in online communities and in print copies through “"zines.” In Hager v. ECW Press Ltd., Reed J. notes that "the use contemplated by private study ... is not one in which the copied work is communicated to the public." ${ }^{\circ 0}$ As well, in Boudreau, the Ontario Court of Justice stated that material distributed to "all ... members of [a] class of students ... does not qualify as 'private study.",61 Following Hager and Boudreau, a court would likely find that the act of distribution removes rewrites from the fair dealing category of private study.

Though many news reports have discussed rewrites (particularly news reports issued around the time that The Wind Done Gone was released), it is unlikely that many rewrites will have been created for the purpose of news reporting. As a result, this category will likely be of little assistance to most authors of rewrites. $R$. $v$. James Lorimer \& Co. is the leading

CCH Canadian, ibid. [footnotes omitted].

Ibid.

Ibid.

Ibid. at para. 51.

(1998), [1999] 2 F.C. 287 at para. 55 (T.D.) [Hager].

Boudreau, supra note 54 at para. 50 . 
case interpreting the term "review" in Canada. ${ }^{62}$ In Lorimer, Mahoney J., citing the trial judge, noted that fair dealing for the purpose of review "requires as a minimum some dealing with the work other than simply condensing it into an abridged version and reproducing it under the author's name." 63 Rewrites do far more than merely condense the work into an abridged version. They add original content, different perspectives, and sometimes completely flesh out characters that may have been given only a name or a minor role in the original text. Thus, it is possible that rewrites that comment on the original text could be seen as having been created for the purpose of review. Such an interpretation of the review category of fair dealing could potentially provide broad cover for many rewrites.

Many rewrites are critical. While some critique the original work, others critique society, using the copyright-protected work as the vehicle through which the criticism occurs. Rewrites that imitate the original work in order to critique it can be seen as falling within the traditional conception of parody. ${ }^{64}$ Rewrites that use the original work in order to critique something else can be seen as "weapon parodies" or satire. ${ }^{65}$ Do these types of criticism fall within the fair dealing category of "criticism"? Canadian courts have noted that, for the purposes of the fair dealing defence, the "object of criticism" 66 can be the style of the work, the ideas set out in the work, the work's "social or moral implications," 67 or the "text or composition of a work." 68

Canadian courts, however, have consistently rejected parody defences to copyright infringement. In 1967, the year of Canada's Centennial, the Exchequer Court of Canada granted an injunction barring the sale of a parody of Woody Guthrie’s song “This Land is Your Land," which replaced the original lyrics with lyrics that "gently chid[ed] the Canadian Government and the Canadian people for their alleged feelings of inferiority." ${ }^{69}$ In 1976, the Gillberry \& Hawke Advertising Agency was made to pay infringement damages and punitive and exemplary damages for having created a parody of the musical work "Downtown," which was to be used in a commercial for a car dealership in Ottawa. ${ }^{70}$ In 1982, in the midst of contentious constitutional reform, the Ontario High Court of Justice issued an injunction restraining Rogers Radio Broadcasting Ltd. from using the music from the Lennon and McCartney song "Revolution” in their parody entitled "Constitution."71

The leading case to address the specific issue of whether the fair dealing category of criticism encompasses parody is Michelin. ${ }^{72}$ In this case, Teitelbaum J. rejected the contention that criticism, under the Copyright Act, encompasses parody. This conclusion, however, was based on the view that "exceptions to copyright infringement should be strictly

(1983), [1984] 1 F.C. 1065 (C.A.) [Lorimer].

Ibid. at 1077.

Ellen Gredley \& Spyros Maniatis, "Parody: A Fatal Attraction? Part 1: The Nature of Parody and its Treatment in Copyright” (1997) 19 Eur. I.P. Rev. 339 at 341.

Michael Spence, "Intellectual Property and the Problem of Parody” (1998) 114 Law Q. Rev. 594 at 59495.

Hager, supra note 60 at para. 58.

Fraser Health Authority v. H.E.U., 2003 BCSC 807, 226 D.L.R. (4th) 563 at para. 63.

Hager, supra note 60 at para. 58

Ludlow Music Inc. v. Canint Music Corp., [1967] 2 Ex. C.R. 109 at 118.

MCA Canada Ltd. v. Gillberry \& Hawke Advertising Agency Ltd. (1976), 28 C.P.R. (2d) 52 (F.C.T.D.). ATV Music Publishing of Canada Ltd. v. Rogers Radio Broadcasting Ltd. (1982), 35 O.R. (2d) 417 (S.C.).

Michelin, supra note 54 at para. 68. 
interpreted."73 As noted above, the Supreme Court of Canada overruled this approach in $\mathrm{CCH}$ Canadian. Future courts, required by the Supreme Court to give a "large and liberal interpretation" to the categories of fair dealing, ${ }^{74}$ may determine that "criticism" encompasses parody and satire. Both Professor Giuseppina D’Agostino and Professor Emir Aly CrownMohammed have suggested that, as a result of the Supreme Court's decision in $\mathrm{CCH}$ Canadian, the fair dealing category of criticism encompasses parody. ${ }^{75}$ However, until a future court determines that, as a result of the Supreme Court's decision in CCH Canadian, some types of parodies (namely critical parodies) can be protected under the fair dealing category of criticism, Teitelbaum J.'s conclusion that parody is not protected under the fair dealing defence remains the law in Canada.

As noted above, rewrites that use the copyright-protected work to critique something other than the work itself can be described as "weapon parodies" or as satire. ${ }^{76}$ Canadian courts could determine that since there may be other ways in which the target could be attacked other than by using the copyright-protected work as the vehicle for attack, satire should not receive protection under fair dealing. While Canadian courts have not addressed the issue of whether satire is protected under fair dealing, the United States Supreme Court, in Campbell v. Acuff-Rose Music, has commented on the possible protection of satire within the U.S. fair use defence. ${ }^{77}$ In Campbell, the leading U.S. decision on parody and fair use, the U.S. Supreme Court distinguished satire from parody. Justice Souter, delivering the Opinion of the Court, stated that

[p]arody needs to mimic an original to make its point, and so has some claim to use the creation of its victim's (or collective victims') imagination, whereas satire can stand on its own two feet and so requires justification for the very act of borrowing. ${ }^{78}$

Rather than taking the position that criticism does not encompass weapon parodies or satire, Canadian courts could require the author who created the rewrite to justify the act of borrowing, most likely in the third step of the fair dealing analysis where the court must determine whether the work was dealt with in a fair manner.

Even if future courts adopt an expansive interpretation of criticism that encompasses critical parodies and satire, however, some rewrites still cannot be considered to have been created for the purpose of criticism. Rather, they may have been created for the purpose of helping empower marginalized groups by placing the marginalized group at the centre of mainstream cultural discourse. To force this type of rewrite within the category of criticism in order to fit it within the list of acceptable fair dealing purposes (and thus have the rewrite deemed non-infringing) might distort the original intention of the author. If the rewrite cannot

Ibid. at para. 63.

CCH Canadian, supra note 43 at para. 51.

Giuseppina D’Agostino, “Healing Fair Dealing? A Comparative Copyright Analysis of Canada’s Fair Dealing to U.K. Fair Dealing and U.S. Fair Use” (2008) 53 McGill L.J. 309; Emir Aly CrowneMohammed, "Parody as fair dealing in Canada: a guide for lawyers and judges" (2009) 4 Journal of Intellectual Property Law \& Practice 468.

Spence, supra note 65 at 594-95; Andrew Watt, "Parody and Post-Modernism: The Story of Negativland” (2002) 25 Colum. J.L. \& Arts 171 at 182.

510 U.S. 569 (1994) [Campbell]. Fair use is the analogous U.S. defence to Canada's fair dealing defence.

Ibid. at 580-81. 
be considered criticism, however, it would likely fall outside of the fair dealing purposes, and would thus be considered to infringe copyright.

There is a strong possibility that some works that rewrite culturally significant works from the perspective of marginalized groups will fall outside of the fair dealing purposes as listed in the Copyright Act. On the assumption that some of these rewrites would fall within the fair dealing purposes, however, this Part will proceed to discuss the second step in the fair dealing analysis.

This step applies only to works created for the purpose of criticism, review, or news reporting. These works, in order to receive protection from the fair dealing defence, must mention both the source of the original work and the name of the author of the original work. ${ }^{79}$ Some rewrites may explicitly mention the work that is being rewritten. For instance, Gone With the Wind is referenced on the back cover of The Wind Done Gone. Other rewrites, however, may not mention, by name, the work that is being rewritten. These rewrites would fail the second step of the fair dealing analysis. In many rewrites, however, the identity of the author and the source of the original work may be evident from the rewrite itself. As a result, it can be argued that authors of these rewrite should not be required to explicitly mention the author of the original work or the source of the original work. In Michelin, this suggestion was made with respect to parodies, and was rejected by Teitelbaum J. After CCH Canadian, however, which adopted a more liberal approach to fair dealing, future courts may determine that it is not necessary to make an explicit reference to the original work in order to satisfy the second step of the fair dealing analysis.

The third step of the fair dealing analysis requires courts to determine whether the work was dealt with in a fair manner. Various factors should be considered in assessing whether "fairness" has been established, including the purpose of the dealing, the character of the dealing, the amount of the dealing, alternatives to the dealing, the nature of the work, and the effect of the dealing on the work. ${ }^{80}$ The first factor to be considered in assessing whether the work has been dealt with in a fair manner is the purpose of the dealing. This factor will tend to fairness if the work was created for one of the purposes set out in the Copyright Act ("namely research, private study, criticism, review or news reporting”). ${ }^{81}$ Many rewrites are created for the purpose of criticizing either the original work or society. What is unclear, however, is whether some of these forms of criticism - namely critical parodies and satire - are protected under fair dealing. Rewrites that do not fall within any of the fair dealing categories (for instance, rewrites created for the purpose of helping empower marginalized groups or rewrites for the purposes of parody and satire if it is determined that these forms of criticism are not protected under the fair dealing defence) will not be protected by the fair dealing defence.

The character of the dealing, the second factor to be considered in the fairness analysis, examines how the works were dealt with. In $\mathrm{CCH}$ Canadian, the Supreme Court of Canada stated that the wide distribution of multiple copies of the original will tend to be unfair. ${ }^{82}$ The 
creation of rewrites, however, does not involve the wide distribution of multiple copies of works. Rather, rewrites involve some reworking or recasting of the original work. Though rewrites may receive a wide distribution (either online or in print), the original works themselves are not distributed. Rewrites that rework the original, culturally significant text to a significant degree would likely tend towards fairness under this factor. However, rewrites that are distributed widely and that reproduce the original work with only minimal recasting or reimagination would likely tend to unfairness under this factor.

The amount of the dealing varies depending on the rewrite in question. Some rewrites, such as Wide Sargasso Sea, take a character from the original work and set them in a completely new context. Such a rewrite may use less of the original work than a rewrite like The Wind Done Gone, which reimagines an entire work from a different perspective. Rewrites that use large portions of copyright-protected works are not removed from the ambit of the fair dealing defence simply due to that fact alone. In Allen v. Toronto Star Newspapers Ltd., ${ }^{83}$ for instance, the Ontario Court (General Division) determined that the act of reproducing a copyright-protected photograph in its entirety, in the context of a newspaper article, was protected by fair dealing.

The fourth factor to be considered in determining whether the dealing is fair asks whether there are alternatives to the dealing. In examining this factor, one must determine the purpose of the rewrite. If the purpose of the rewrite is to critique the underinclusiveness of a certain text, then it is difficult to see how the critique could have been as effective if it had not reproduced certain elements of the original text. As noted by Keith Green:

It is possible to argue that there is no point in spending yet more time on the works of dead white men, when writers could be creating entirely fresh fictions out of their own specific experience, be it Canadian, Caribbean, African American or whatever. However, this would be to miss the point of the 'writing back' process. Canonical English literatures may have marginalised the colonial subject, but nevertheless, canonical English literature was and is very much part of the reading of English-speaking peoples around the world, not just those from Britain. This schooling is not easily forgotten, and many writers have chosen to deal with the ideological assumptions of the traditional literary canon by creating a 'counter-discourse', a form of writing which resists the powerful influence of empire not by denying it but by engaging with it. ${ }^{84}$

As well, if the purpose of the rewrite is to help a marginalized group achieve a level of empowerment by writing that marginalized group into a culturally significant text, it is difficult to see any alternative to using the culturally significant text itself. This factor should tend towards fairness for most rewrites of culturally significant texts done for the purpose of criticizing the original work or empowering marginalized groups.

The nature of the work is the fifth factor to be considered in determining whether the dealing was fair. In CCH Canadian, the Supreme Court notes that the use of unpublished, nonconfidential works may tend towards a finding of fairness. ${ }^{85}$ It also notes that the use of

(1997), 36 O.R. (3d) 201 (Ct. J. (Gen. Div.)).

Keith Green \& Jill LeBihan, Critical Theory and Practice: A Coursebook (New York: Routledge, 1996) at 283.

CCH Canadian, supra note 43 at para. 58. 
confidential works "may tip the scales towards finding that the dealing was unfair." ${ }^{86}$ The overwhelming majority of rewrites do not use unpublished or confidential works. Rather, authors who create rewrites do so from texts that are public and have achieved a degree of cultural significance through critical review, marketing, or their ubiquitous presence in popular culture. As a result, this factor is neutral in the fairness analysis.

The final factor to be considered is the effect of the dealing on the work. The Supreme Court of Canada, in discussing this factor, notes that "[i]f the reproduced work is likely to compete with the market of the original work, this may suggest that the dealing is not fair." 7 It is unlikely that works which rewrite texts from the perspectives of marginalized groups will compete with the market for the original work. Consumers looking to read the original Mitchell text will not substitute The Wind Done Gone for Gone With The Wind. Fans of classic Star Trek episodes seeking out those episodes will not substitute Star Trek fan fiction that reimagines the entire crew as Aboriginal peoples for the original Star Trek episodes.

A particularly successful critical rewrite may cause readers or viewers to see the original work in a new light, resulting in negative effects on the market for the original work. However, as noted by the U.S. Supreme Court in Campbell in the context of a discussion on parody and copyright infringement, a distinction could be drawn between a parody that suppresses demand for a work and one that usurps demand for a work. ${ }^{88}$ In the U.S., the latter is actionable, while the former is not. ${ }^{89}$ Canadian courts have not addressed this question. It is likely, however, that most works that rewrite culturally significant texts from the perspective of marginalized groups, if they impact the demand for the original work at all, suppress rather than usurp that demand. This factor would likely tend towards fairness.

As this Part has demonstrated, some rewrites will not be protected by the fair dealing defence. Though many rewrites will likely mention the source and author of the original works and will generally tend towards fairness (thus satisfying the second and third steps of the fair dealing test), it is likely that a significant number of rewrites will fall outside of the listed fair dealing purposes, failing the first step of the fair dealing analysis. These rewrites will be considered to infringe copyright, and can be enjoined by the copyright owner.

\section{REWRITES AND MORAL RIGHTS INFRINGEMENT}

Individuals that create rewritten versions of texts, in addition to facing an action for copyright infringement brought by the copyright owner, may also face an action for moral rights infringement brought by the work's original author. Moral rights "treat the artist's oeuvre as an extension of his or her personality, possessing a dignity which is deserving of protection." 90 While copyright is concerned with protecting the economic interests of the author, moral rights protect the author's non-commercial interests. ${ }^{91}$ They take a "more

Ibid.

Ibid. at para. 59.

Supra note 77.

Ibid.

Théberge, supra note 20 at para. 15.

Jonathan Herman, "Moral Rights and Canadian Copyright Reform: The Impact on Motion Picture Creators” (1990) 20 R.D.U.S. 407. 
elevated and less dollars and cents view of the relationship between an artist and his or her work." 92

In Canada, moral rights are protected under the Copyright Act. Authors of works have two moral rights: the right to the integrity of the work and the right to paternity of the work that is to say, "the right, where reasonable in the circumstances, to be associated with the work as its author by name or under a pseudonym [or] the right to remain anonymous." 93

In Canada, the right of integrity is infringed either where the work is "distorted, mutilated or otherwise modified" "to the prejudice of the honour or reputation of the author"; or where the work is "used in association with a product, service, cause or institution to the prejudice of the honour or reputation of the author." 94 Courts apply a subjective-objective test to determine whether a distortion, mutilation, modification, or association is prejudicial to the author's honour or reputation. The author must feel that the distortion, mutilation, modification, or association is prejudicial to their honour or reputation. The author's opinion must be supported through objective evidence such as the opinion of a number of other "well respected artists and people knowledgeable in [the] field," 95 whether the number of lectures the author was asked to give fell after the publication of the distorted version of the author's work, ${ }^{96}$ whether the author was ridiculed or mocked by his colleagues or the newspapers, or whether the author had heard any complaints about the distorted work. ${ }^{97}$

Most rewrites will not run afoul of the moral right of paternity. Grace Westcott notes that "fan fiction generally does not try to pass itself off as being the work of the original author. Most fan sites carry disclaimers acknowledging their borrowing," and acknowledging the works upon which they are based. ${ }^{98}$ The same is likely true for many rewrites created by established authors. As noted above, The Wind Done Gone references Gone With The Wind on the back cover. Jane Eyre is referenced in the introduction to Wide Sargasso Sea. ${ }^{99}$

The moral right of integrity, however, may be infringed through the creation of rewrites. A court would likely consider a rewrite to be a distortion, mutilation, or modification of the original work. The Wind Done Gone, for example, changes the message of Gone With The Wind, distorts its characters, and modifies the setting. In "Friction over Fan Fiction," Westcott states that

an author may well feel that something he or she has spent years researching and writing is a finished work, not a literary buffet or a cultural spare parts counter for others to rummage in. An author may object to distortions of his characters when they are appropriated to the divergent narrative sensibilities of fan imaginations. $^{100}$

\footnotetext{
Théberge, supra note 20 at para. 15. Copyright Act, supra note 19, s. 14.1(1).

Ibid., s. 28.2(1).

Snow v. Eaton Centre Ltd. (1982), 70 C.P.R. (2d) 105 at 106 (Ont. H.C.).

Prise de Parole Inc. v. Guérin, Éditeur Ltée. (1995), 104 F.T.R. 104 at para. 27 (T.D.).

Ibid.

Grace Westcott, “Friction over Fan Fiction: Is this burgeoning art form legal?” Literary Review of Canada (1 July 2008), online: Literary Review of Canada <http://reviewcanada.ca/essays/2008/07/01/ friction-over-fan-fiction>.

99 Francis Wyndham, "Introduction” in Rhys, supra note 31, 5 at 11-12. Supra note 98. 
In order for any distortion to amount to an infringement of moral rights, however, the author's belief that the distortion is prejudicial to their honour or reputation must be supported by objective evidence. If a court determines that an author's moral rights have been infringed through the creation of a rewrite, the court could enjoin any further distribution of the rewrite and order the individual who created the rewrite to pay damages, among other remedies. ${ }^{101}$

\section{POSSIBILITIES FOR REFORM}

As the above analysis has demonstrated, it is likely that Canadian courts will find that some works that rewrite culturally significant texts from the perspective of marginalized groups prima facie infringe copyright and cannot be saved by fair dealing. These rewrites may also infringe an author's moral rights. This article will conclude by suggesting five amendments to the Copyright Act that can be explored in seeking to create a legal space within which such rewrites can be created. Some of these amendments have been proposed in Bill C-32. This article will discuss each of these amendments only briefly, as each merits their own, complete analysis that is beyond the scope of this article to address.

First, the substantial taking test could be modified to take into consideration the extent to which the new work is transformative. As noted above, s. 3(1) of the Copyright Act states that the copyright owner has the exclusive right to reproduce a work either in its entirety or a substantial part of a work. Courts have stated that the question of whether a taking is "substantial" is more related to the quality of the taking than the quantity of the taking. ${ }^{102}$ Section 3(1) could be revised to indicate that a taking is not deemed substantial if the amount taken (regardless of its qualitative or quantitative significance) is sufficiently transformed, reworked, or reimagined in the new work. This amendment would potentially render noninfringing many works that rewrite culturally significant texts from the perspective of marginalized groups. In most cases, these rewrites transform the original work, reimagining it, recasting it, or recreating it for a new purpose. This potential reform, however, is open to concerns that it is overloaded.

Second, legal space could be created through the addition of parody and satire defences to the Copyright Act. Although commentators argue that after CCH Canadian parodies (at least those that are critical) are protected under the fair dealing category of criticism, the spectre of Michelin, and the unequivocal statement of Teitelbaum J. that “criticism,” under the fair dealing defence does not encompass parody, still loom large in Canadian copyright law. For instance, in a 2008 decision involving a parody of the Vancouver Sun, Master Donaldson of the British Columbia Supreme Court followed Michelin in stating that parody "is not an exception to copyright infringement under the Copyright Act, and therefore does not constitute a defence” to copyright infringement. ${ }^{103}$ Master Donaldson reached this conclusion without referring to CCH Canadian. 
One way to ensure that individuals can create rewrites that can be classified as parodies or satire without infringing copyright, therefore, without relying on a court decision to overturn the decision of Teitelbaum J. in Michelin, is to amend the Copyright Act to include parody and satire defences to copyright infringement. ${ }^{104}$ In order to ensure that these newly created user rights are not overbroad, the parody and satire defences could be incorporated within fair dealing as the sixth and seventh fair dealing categories. Individuals would then have the right to use a substantial amount of copyright-protected expression without the permission of the copyright owner for the purpose of parody or satire, provided they do so in a fair manner. Fairness, as is the case with the current list of five fair dealing purposes, would be determined through an analysis of various factors, which include: the purpose of the dealing, the character of the dealing, the amount of the dealing, the alternatives to the dealing, the nature of the work, and the effect of the dealing on the work. This proposal has been incorporated into Bill C-32. ${ }^{105}$

A parody and satire defence would render many rewrites non-infringing, such as The Wind Done Gone and Wide Sargasso Sea. Those rewrites that could not be considered parodies or satire, however, such as those done for the purpose of empowering marginalized groups by reimagining culturally significant texts from the perspectives of those marginalized groups, would likely still be considered to infringe copyright.

A third possible amendment that would permit the creation and dissemination of rewrites of culturally significant texts from the perspective of marginalized groups is to incorporate, within the Copyright Act, a right to engage in the transformative use of copyright-protected expression. Transformative works can be seen as works that rework copyright-protected material "for a new purpose or with a new meaning." ${ }^{06}$ As noted above, many rewrites can be considered to be tranformative works.

See Howard Knopf, "Why Canada Needs Parody Parity and Comedy Comity — Copyright Control of Canadian Humour” (2008) 20 Les Cahiers de Propriété Intellectuelle 717 at 721; Graham Reynolds, "Necessarily Critical? The Adoption of a Parody Defence to Copyright Infringement in Canada" (2010) Man. L.J. [forthcoming].

105 Supra note 23. One problematic aspect of Bill C-32 that merits attention is the legal protection that it grants to technological protection measures (TPMs). TPMs, sometimes referred to as "digital locks," allow copyright owners and distributors to restrict access to and the use of works. Bill C-32 makes it an offence to circumvent an access control TPM for all purposes save those that are expressly excepted. Though a variety of purposes are excepted, fair dealing is not. Thus, if these provisions of Bill C-32 are brought into law, an individual could commit an offence by circumventing an access control TPM in order to exercise their right to fair dealing. These provisions undermine many of the positive aspects of Bill C-32 - such as the expansion of fair dealing to include categories of parody, satire, and education - and should be amended during Canada's ongoing process of copyright reform. One possible amendment is to revise the TPM provisions contained in Bill C-32 to indicate that it is not an offence to circumvent an access control TPM in order to engage in an act that is otherwise lawful.

106 U.K., HM Treasury, Gowers Review of Intellectual Property by Andrew Gowers, (London: Her Majesty’s Stationery Office, 2006) at 66. See also Pierre N. Leval, “Toward a Fair Use Standard” (1990) 103 Harv. L. Rev. 1105 at 1111. In this work, Judge Leval defines the term "transformative use" as follows:

The use must be productive and must the quoted matter in a different manner or for a different purpose from the original. A quotation of copyrighted material that merely repackages or republishes the original is unlikely to pass the test; in Justice Story's words, it would merely "supersede the objects" of the original. If, on the other hand, the secondary use adds value to the original - if the quoted matter is used as raw material, transformed in the creation of new information, new aesthetics, new insights and understandings - this is the very type of activity that the fair use doctrine intends to protect for the enrichment of society. Transformative uses may include criticizing the quoted work, exposing the character of the original author, proving a fact, or summarizing an idea argued in the original in order to defend or rebut it. They also may include parody, symbolism, aesthetic declarations, and innumerable other uses [footnotes omitted] 
In a manner similar to the proposed parody and satire defences, this right could be incorporated within fair dealing as an additional fair dealing category. Individuals would then have the right, under fair dealing, to use a substantial amount of copyright-protected expression without the permission of the copyright owner for the purpose of engaging in the transformative use of copyright-protected expression, provided they do so in a fair manner. This right is broader than the right to use copyright-protected expression for the purposes of parody and satire proposed above. While it would encompass rewrites created for the purpose of parody and satire, a right to engage in fair transformative use would also encompass many rewrites created for other purposes, such as empowering marginalized groups.

A fourth potential amendment that could be explored in seeking to develop a legal space for the creation and distribution of rewrites is the adoption of a defence permitting the use of existing expression in the creation of new expression, provided the use is done for noncommercial purposes. Such a defence, a variation of which has been proposed in Bill C-32, ${ }^{107}$ is both broader and narrower than the right to engage in fair transformative use proposed above. It is broader, in that the new work is not required to transform the existing work that it has incorporated. It is also narrower, in that the use must be done for non-commercial purposes. Such a defence would thus not protect, from claims of copyright infringement, rewrites that are sold commercially. It would, however, render non-infringing all noncommercial rewrites of culturally significant texts from the perspective of marginalized groups, even if the rewrites are not deemed to transform the original text.

A fifth potential amendment involves the expansion of fair dealing so that it serves as a defence to both copyright and moral rights infringement. Currently, fair dealing is not a defence to moral rights infringement. As a result, even if a rewrite is deemed not to infringe copyright due to the application of fair dealing, it may still violate the author's moral rights. As part of this reform, ss. 29, 29.1, and 29.2 of the Copyright Act could be revised to indicate that fair dealing does not infringe copyright or violate moral rights.

Bill C-32, supra note 23, cl. 22. This defence states that:

29.21(1) It is not an infringement of copyright for an individual to use an existing work or other subject-matter or copy of one, which has been published or otherwise made available to the public, in the creation of a new work or other subject-matter in which copyright subsists and for the individual - or, with the individual's authorization, a member of their household - to use the new work or other subject-matter or to authorize an intermediary to disseminate it, if

(a) the use of, or the authorization to disseminate, the new work or other subject-matter is done solely for non-commercial purposes;

(b) the source - and, if given in the source, the name of the author, performer, maker or broadcaster - of the existing work or other subject-matter or copy of it are mentioned, if it is reasonable in the circumstances to do so;

(c) the individual had reasonable grounds to believe that the existing work or other subjectmatter or copy of it, as the case may be, was not infringing copyright; and

(d) the use of, or the authorization to disseminate, the new work or other subject-matter does not have a substantial adverse effect, financial or otherwise, on the exploitation or potential exploitation of the existing work or other subject-matter - or copy of it - or on an existing or potential market for it, including that the new work or other subjectmatter is not a substitute for the existing one. 


\section{CONCLUSION}

Works that rewrite culturally significant texts from the perspective of marginalized groups serve important social purposes. They challenge stereotypes, upend "dominant cultural norms," supply missing voices, and empower marginalized groups by reimagining culturally significant texts from alternative perspectives, thus "granting agency to those denied it in the popular mythology."108

As demonstrated in this article, however, some of these rewrites would likely be found to infringe copyright. They may also be found to violate the author's moral rights. These determinations may have no impact on some authors, who will continue to rework and reimagine culturally significant texts from the perspectives of marginalized groups regardless of whether, in so doing, they infringe copyright and violate moral rights. Nevertheless, the risk of infringing copyright and violating moral rights may deter other authors from rewriting works that are still protected by copyright.

This article has argued that, given the important social benefits at stake, the acts of creating and disseminating works that rewrite culturally significant texts from the perspective of marginalized groups ought not to infringe copyright and violate moral rights. To this end, this article has suggested five amendments to the Copyright Act. Specifically, it has proposed an amendment to the substantial taking requirement, the adoption of parody and satire defences, the adoption of a right to engage in the transformative use of copyright-protected expression, the adoption of a right to use existing expression in the creation of new expression, provided the use was done for non-commercial purposes, and the expansion of fair dealing to act as a defence to moral rights violations. Some of these amendments have been proposed in Bill C-32, the Government of Canada's latest attempt to reform the Copyright Act.

The adoption of the amendments proposed in this article would legalize a powerful tool of criticism and empowerment for marginalized groups, while maintaining both the rights of the copyright owner to control the commercial exploitation of their work and the ability of the author to restrain certain mutilations, distortions, and modifications of their work. Failing to incorporate these amendments into a revised Copyright Act will maintain the status quo, in which the voices of marginalized groups, expressed through the rewriting of culturally significant texts, can be silenced at the whim of copyright owners and authors. 